\title{
Indonesia 1939-1942: Prelude to the Japanese Occupation
}

\author{
Shigeru Sato
}

In the conventional historiography of Indonesia, the Second World War is equated with the Japanese occupation, and 1942 is a year of sudden change. This article argues that there was a prelude to these conditions. Changes in the global economic structure due to the Second World War, and countermeasures by the state authorities, began well before the Japanese invasion. The fundamental problem was the gradually deepening economic isolation that necessitated state intervention.

On 17 August 1945, two days after Japan surrendered, Indonesia declared independence and a national revolution ensued. Since then it has become a historiographical convention to view the Japanese occupation as a prelude to Indonesian independence. ${ }^{1}$ Decades later, when Japan's increasing economic influence in Southeast Asia came to alarm some observers, a tendency emerged among historians to seek a prelude to this phenomenon in Japan's pre-war economic penetration into Southeast Asia. Japan's military expansionism in the Second World War ended as a crushing blow to Japan but, according to this view, it effectively removed the Dutch colonial order and prepared the road for Japan's post-war 'peaceful expansionism' that had begun in the interwar period. ${ }^{2}$ Both perspectives examine Japan's pre-1945 expansion to explain the post-war phenomena. This article, in contrast, focuses on the years before the Japanese invasion with the goal of examining the socio-economic impact of the Japanese occupation in a historical context.

The Netherlands Indies authorities had long suspected that Japan's pre-war economic penetration into their colony was a prelude to a subsequent military invasion,

Shigeru Sato is a Lecturer at the University of Newcastle. He may be contacted at Shigeru.Sato@ newcastle.edu.au. An earlier version of this article was drafted as a working paper during a visiting fellowship at the Netherlands Institute for War Documentation (NIOD) in Amsterdam in early 2004. Prof. Sato is grateful to NIOD and its staff for their support

1 One example among many is Benedict R.O'G. Anderson, Java in a time of revolution: Occupation and resistance, 1944-1946 (Ithaca: Cornell University Press, 1972).

2 Howard Dick, 'Japan's economic expansion in the Netherlands Indies between the First and Second World Wars', Journal of Southeast Asian Studies, 20, 2 (Sept. 1989): 244-72; Anne Booth, 'Japanese import penetration and Dutch response: Some aspects of economic policy making in colonial Indonesia', in International commercial rivalry in Southeast Asia in the interwar period, ed. Shinya Sugiyama and Milagros C. Guerrero (New Haven: Yale Southeast Asia Studies, Yale Center for International and Area Studies, 1994), pp. 133-64. 
regarding even Japanese commoners, such as fishermen and retailers, as possible spies. ${ }^{3}$ Dutch suspicions were reinforced when they saw these Japanese repatriate prior to the invasion and then return together with the invading forces while donning 'military' uniforms. The Japanese occupation forces employed Japanese civilians with some experience in, and knowledge about, Southeast Asia for administrative purposes and provided them with a uniform that was almost identical to the military uniforms. As a result, some Dutch and local people mistook these civilians for military personnel, and imagined that they had clandestinely operated in the pre-war Netherlands Indies by disguising themselves as civilians. The focal point of this article is, however, not Japanese activities but rather Dutch economic policies in Indonesia after 1 September 1939, when the Second World War broke out in Europe as the result of the German invasion of Poland. In Asia before that, Japan and China had been at war for more than two years but the 'war' in Indonesia began on 1 September 1939, at least in the thinking of the Dutch colonial authorities, due to the special relations between the Netherlands and its colonies. The Dutch colonial authorities responded immediately to this event and commenced systematic economic preparations.

The existing literature on Indonesian history depicts early 1942 as a moment of sudden and irrevocable change. Commonly used expressions such as 'the end of the Dutch colonial rule' have created the image of fundamental changes occurring in that year. As far as social and economic changes are concerned, this image is rooted in ignorance about the events before the Japanese invasion. Most economic studies of the so-called 'late colonial era' focus on the Great Depression in the first half of the 1930s and gradual recovery from it in the second half. Their inquiries stop in 1939 or thereabouts, leaving the final few years unmentioned, thus giving a wrong impression, or statements, that nothing noteworthy happened thereafter and the recovery process continued until it was dashed by the Japanese invasion. ${ }^{4}$

In the introduction to the most comprehensive economic study of the Outer Islands of Indonesia in the period 1900-42, Jeroen Touwen reiterates the commonly held view: 'The final period, 1935-1942, showed a slow but steady recovery. During these years, trade regained its impetus and the government strengthened its grip on the economic processes within the colony. After 1942, the economy of colonial Indonesia was disrupted by the Pacific War. ${ }^{5}$ To this he adds a footnote: 'Although the Japanese invasion of the Netherlands Indies began on 10 January 1942, world trade had been seriously disrupted since 1940.' The author was evidently aware of the serious economic changes in the final stage of the Dutch colonial era but he, like so many others, decided not to pay attention to them. The main body of his book hardly touches on the final years, notwithstanding the title of the book that promises otherwise.

3 For a typical document see Ten years of Japanese burrowing in the Netherlands East Indies (New York: Netherlands Information Bureau, 1942).

4 In the field of political history there are studies that present a balanced view on continuity and change in the context of a historical continuum across the 'three eras'. See, among others, George McTurnan Kahin, Nationalism and revolution in Indonesia (Ithaca: Cornell University Press, 1952); and William H. Frederick, Visions and heat: The making of the Indonesian Revolution (Athens: Ohio University Press, 1989). 5 Jeroen Touwen, Extremes in the Archipelago: Trade and economic development in the Outer Islands of Indonesia, 1900-1942 (Leiden: KITLV Press, 2001), pp. 3-4. 
One reason for the virtual silence on the period in question relates to the availability of archival materials. After the Germans invaded the Netherlands and the Dutch government sought refuge in London, communication between the Netherlands and the Netherlands Indies was broken and archival materials on this period are often missing. Economic historians who rely on archives have opted for stopping their research where their source materials stop. Historians, however, should not apply their common excuse that there is insufficient information to this period because there is plenty of information in published materials such as newspapers, government publications and parliamentary proceedings, which closely monitored, reported and discussed the changing circumstances. These materials not only provide information but also lead us to a fundamental revision of the way we look at the impact of the Second World War on Indonesian economy and society. This article traces the general trend of economic changes using these readily available but underutilised sources, and re-examines certain theoretical questions such as causality, continuity, change and legacy.

The disruption in world trade that Touwen referred to is central to the question because it affected all other aspects of economic life in Indonesia. Most of the wartime economic woes in Indonesia appeared already in this phase of the war. In response, the Dutch colonial administration implemented a series of economic countermeasures that were, in essence, designed to prepare the Indies for survival in economic isolation. When the Japanese invaded and occupied, Indonesia became more isolated economically, but the countermeasures prepared by the Dutch were already in place and the Japanese continued them in essence. For this reason we can observe a linear progression, or exacerbation of problems, from the Dutch era to the Japanese era, rather than fundamental changes, in a range of economic matters. The following sections outline the war's impact on the four major socio-economic aspects, namely international trade, industrialisation, food supply and employment. References to the Japanese period will be made wherever appropriate in order to clarify in what ways the period in question was a prelude to the Japanese occupation.

\section{International trade}

Until the worldwide economic depression of the 1930s, Indonesian society was predominantly agrarian. It exported agricultural and mining products, and imported industrial goods from the West and Japan, and rice from Mainland Southeast Asia. The volume of trade expanded rapidly from the late nineteenth century owing to accelerated industrialisation in the West, the revolutionary improvement in the means of transport, and laissez-faire policies adopted in Indonesia after 1870. A turning point came in 1930 when the Depression began to affect the Indonesian economy, followed by two more turning points within the same decade: the bottom of the trough in the middle of the 1930s with a partial recovery thereafter, and the impact of the European war at its end.

The outbreak of the war in Europe created much confusion, anxiety and anticipation in the Netherlands Indies. Some of the initial reactions in the business world were positive. The Netherlands had reaped substantial economic profits during the First World War. Some therefore anticipated similar opportunities to arise. On 5 September 1939 a Dutch daily in Java reported that 14 footwear factories in Northampton, England had received an order for two million pairs of military boots and had begun working at full capacity. Over the following two days the same paper wrote that the sale of 
kapok from the Netherlands Indies was expected to rise by 50 per cent in volume and 100 per cent in value. ${ }^{6}$ The boom in the first month of war proved much better than anticipated. The export of kapok increased more than fivefold, both in weight and value in comparison with August. That was because the Dutch government placed a large order for this important material for aircraft insulation and life jackets. ${ }^{7}$

Major export items such as sugar and tea also enjoyed a boom due to military stockpiling and business speculation. In the month of September 1939 the overall export tonnage from Java and Madura was recorded at 327,000 metric tonnes, a remarkable increase from 179,000 metric tonnes a year earlier. ${ }^{8}$ This boom was, however, accompanied by negative side effects. Marine insurance companies decided on 1 September 1939 to raise their insurance premiums by 50 per cent as of the following day. ${ }^{9}$ The price of fuel for ships also rose, as coal dealers also raised their prices. Moreover, the sea routes via the Suez Canal and the Mediterranean Sea became too perilous, so most ships reverted to the route via the Cape of Good Hope. Consequently, the freight rate to Europe rose in relative terms from 100 in August to 157 in September 1939, and 207 in February 1940. Freight rates to the east coast of North America also rose from 100 in August to 125 in September 1939, and to 180 by April $1941 .{ }^{10}$ The belligerent countries' governments and militaries began to commandeer or control large cargo ships. The Netherlands remained politically neutral for several months but destruction of Dutch ships nonetheless commenced and 20 per cent of the entire Dutch merchant marine had been lost by 1 July $1941 .{ }^{11}$

The war created other obstacles in the way of production and packing of export items. Fertilisers for agricultural estates became more expensive and harder to obtain. Tea was exported in triplex cases insulated with aluminium foil, imported from northeastern Europe. Importation of these cases stopped, and this caused consternation among people in the industry. Wooden cases in which to export rubber also became difficult to obtain. Sugar, coffee, tapioca and rice had to be packed in gunnysacks imported from British India. In September 1939 the British defence forces began to make a requisition of four million sacks per week for making sandbags. This instantly halved the number of sacks available for civilian purposes. The Netherlands Indies Army also placed a 'great order' of sacks for the same purpose. The availability of sacks for business dropped and the prices rose. The Netherlands Indies Department of Economic Affairs started urgent attempts to produce sacks from locally available fibres such as roselle, sisal and miscellaneous plants found in the forest. They converted tobacco plantations in Deli partly to fields of fibre-yielding crops and built fibre-processing factories. These attempts, however, fell short of solving the problem. ${ }^{12}$

6 De Java-Bode, 5, 6 and 7 Sept. 1939; De Locomotief, 6, 7, 8 and 9 Sept. 1939.

7 Economisch Weekblad voor Nederlandsch-Indë [Economic Weekly for the Netherlands Indies], (23 Feb. 1940): 297.

8 De Locomotief, 14 Oct. 1939.

9 De Locomotief, 4 Sept. 1939; De Java-Bode, 3 Nov. and 2 Dec. 1939.

10 Economisch Weekblad (8 Dec. 1939): 2005; (5 Jan. 1940): 1; (3 May 1940): 871; (10 May 1940): 11; and De Java-Bode, 4 and 18 Aug. 1941.

11 De Java-Bode, 18 Aug. 1941.

12 Economisch Weekblad (22 Mar. 1940): 466-7; (13 Sept. 1940): 1669; (7 Feb. 1941): 207-8; De Java-Bode 31 Oct., 3 Nov., 2 and 7 Dec. 1939; 14 Feb. and 14 Mar. 1940; 25 Mar. 1941. 
The main obstacle for trading was closure of markets. After the First World War the markets for Indonesia's export industries had diversified to an extent but dependence on Europe was still heavy. As the war spread in Europe, Indonesia's export industries gradually lost markets. The aggregate tonnage of agricultural produce exported from Indonesia dropped 25 per cent in 1940 despite the boom in the first few months. ${ }^{13}$ The gross tonnage of agricultural exports in 1941, scheduled to be released in Indisch Verslag 1942, was not published, but the general trend can be observed from many official interim reports. For instance, exportation from Sumatra's East Coast in the first six months of 1941 dropped by 21 per cent in value and six per cent in tonnage from the same period a year earlier, and importation fell by 31 per cent in value and 46 per cent in tonnage. The discrepancies between the weights and the values indicate that export items became much cheaper whereas import items became more expensive. ${ }^{14}$

Despite this general trend, certain items such as rubber and tin continued to boom. Rubber was Indonesia's most important export item before the war. The total value of exports in 1939 was 746 million guilders, of which rubber was responsible for 197 million guilders, followed by petroleum and petroleum products (159 million guilders) and sugar (78 million guilders). ${ }^{15}$ At the beginning of the twentieth century, production of rubber spread rapidly in Sumatra, Borneo and West Java. By 1929 Indonesia was producing nearly half of the world's supply. After 1940, rubber too lost its European markets but increased demands from the United States more than compensated for the loss. Even before 1942, the United States consumed over half of the world's rubber, and this demand accelerated with the production of tyres for trucks, jeeps and aeroplanes in preparation for war. Exportation of Indonesian smallholders' rubber rose from 163,000 metric tonnes in 1939 to 274,000 metric tonnes in 1941, and estate rubber from 150,000 to 250,000 metric tonnes. The prices also rose. ${ }^{16}$ Rubber and tin were, however, exceptional items. The sale of most other items fell so much that a Dutch daily in Indonesia reported in early 1941 that rubber had become 'the main cork upon which the Indies now $\operatorname{drift}[\mathrm{ed}] \cdot{ }^{17}$

Copra (dried kernel of the coconut) was one of those items that lost its foreign markets. When the European markets closed, alternative outlets were unavailable due in part to severe competition from other types of edible oil from other areas of the world. Java produced approximately half a million tonnes of copra annually, which was mostly consumed by its own large population. In other, less densely populated regions of the archipelago, copra was one of the most important export items. In 1939 the Outer Islands exported 590,000 tonnes including 61,000 tonnes for Java. The areas along the coastal lines of West Sumatra, Riau, West Kalimantan, North and South Sulawesi and Maluku,

13 Indisch Verslag 1941 [Statistical Yearbook of the Netherlands Indies 1941], pp. 355 and 360.

14 De Java-Bode 2 Aug. and 13 Oct. 1941.

15 Indisch Verslag 1941, pp. 355-7.

16 Economisch Weekblad (13 Oct. 1939): 1704 and 1710; (24 Nov. 1939): 1812; (8 Dec. 1939): 2014; and (20 Dec. 1941): 2348. In 1941, according to Peter Post, an NIOD researcher, the Japanese zaibatsu Mitsui came to be involved in the business of buying rubber from the Netherlands Indies and selling it to the United States (which the US used, of course, in the war against Japan and the other Axis countries).

17 This is the title of a newspaper article, 'Rubber de Voornaamste Kurk Waarop Indië Thans Drijft', published in De Java-Bode (1 Mar. 1941). The same paper also carried an article 'Tin en rubber: Amerika wil alles koopen!' [Tin and rubber: America will buy them all!]. 
were the main copra exporting regions. In Minahasa, from 60 to 70 per cent of the local people's incomes were derived from it. ${ }^{18}$ These regions exported copra and imported rice.

In mid-1940 the volume of copra exportation dropped to a quarter of the pre-war level, and the price also halved. Making a sharp contrast to the booming rubber-growing regions, the lowering of the general standard of living in the coconut growing areas quickly became noticeable. In Minahasa this was reflected statistically in the lowered rates of debt repayments and tax payments, as well as the mode of fulfilment of the herendiensten (obligatory labour services). In the pre-war years, many people paid cash instead of labouring but now fewer people could afford to pay, and more people opted for rendering physical labour. In Manado, owners of coconut trees employed coolies to plant food crops between the trees but food shortages became more serious than before the war. To evade a catastrophic effect on the local population, the government created the Copra Fund in late 1940 and bought certain amounts of copra at a fixed price, 1.5 guilders per 100 kilograms net. This cost the government about 11 million guilders per annum. ${ }^{19}$

Changes in international trade also affected the prices of daily essentials. To regulate commodity prices, the Indies administration issued an ordinance on 1 September 1939 that prohibited traders from raising prices over those on 24 August. ${ }^{20} \mathrm{~A}$ strict implementation of this ordinance, despite heavy penalties, soon proved impossible because some daily essentials, such as clothing materials, were imported. Exporters in the United States raised the price of cotton by 60 per cent; Japanese cotton goods producers who relied on imported cotton also raised the prices of their products, making price controls impossible. By October 1941, the wholesale price of imported foodstuffs had increased some 32 per cent, textiles 55 per cent, chemicals 76 per cent and steel 140 per cent. This affected the prices of domestic products including food. In October 1941, the price of food in Java was on average 14 percent higher than that in September 1939. ${ }^{21}$ Wages for unskilled workers, in contrast, remained static. Moreover, many workers lost their source of income. That was because, as we shall see, the plantations that hastily employed workers in the boom months dismissed even larger numbers of workers when international trade contracted.

\section{Industrialisation}

The contraction in international trade necessitated a degree of industrialisation within Indonesia, both for processing raw materials that previously were exported, and for producing import substitutes. Quinine and paper provide an example of each case. Indonesia had a virtual monopoly of production of cinchona bark from which quinine was made. Military demands for quinine shot up when the war broke out, as synthetic medicines for malaria were still uncommon. Much of the cinchona bark previously was shipped to the Netherlands for processing but the Dutch quinine factories closed when the Germans invaded. This compelled more bark to be processed in Indonesia. The

18 De Java-Bode, 16 Aug. 1940; Economisch Weekblad (30 May 1941): 955-7.

19 Economisch Weekblad (8 Dec. 1939): 2011; (23 Aug. 1940): 1570; (20 Sept. 1940): 1733; (7 Mar. 1941): 367; (30 May 1941): 955-7; (20 Dec. 1941): 2348; De Locomotief, 3 Oct. 1939; Indisch Verslag 1941, p. 355.

20 Staatsblad 1939 [Orders and Decrees 1939], no. 453.

21 Economisch Weekblad (20 Dec. 1941): 2342, 2344, 2351. 
factory in Bandung expanded its operation, and Indonesia's exportation of quinine and quinine salt rose from 163 tonnes in 1939 to 587 tonnes in $1940 .{ }^{22}$

Production of import substitutes demanded more urgent attention. No sooner had the war broken out in Europe than the Dutch colonial authorities were informed that importation of paper from Great Britain and the United States had become impossible. The existing paper factories were small in number and production capacity, so the authorities planned to build a large paper factory on the coast of Aceh, using timber in Aceh's hinterland as raw material. A feasibility study for rafting the timber down the rivers conducted by a specialist invited from Sweden found that transporting timber was technically possible but costly. Disregarding cost-inefficiency, however, the factory had to be built. One extra factory was not enough, so they decided to open another in Laces, East Java. A new industry, however, could not start immediately. A few weeks before the Japanese invasion of Southeast Asia, the Dutch-language newspaper De Java-Bode was still reporting that an American specialist had just completed his review of the project, given some advice and returned to the United States, and that the project was proceeding. ${ }^{23}$

If Indonesia was to become economically self-sufficient, what it needed was not a few factories but a large industrial complex. To start such a complex, certain fundamental industries had to be fostered first with particular emphasis on metal, chemical, glass, textile, wood pulp, plywood and cement industries. The Dutch planned to construct an aluminium factory in Sumatra using the electricity generated at the Asahan Valley and the capital of some 30 million guilders over a period of 20 months. For many of the other industries, they envisaged an industrial belt in the area along the North Coast of Java, stretching from Surabaya to Rembang. One reason for the selection of this region was that various raw materials for the industries, such as silica sand for glass and cotton for textiles, were either available or could be made available in this area. Another reason was that this region was one of the most impoverished areas known as the 'honger-gebied" (hunger zone). So it was thought that industries would provide the local people with opportunities to earn more income. In Semarang, they also began to construct a dry dock where ships of up to 10,000 tonnes could be built. ${ }^{24}$

These new industries had to be launched in the face of many obstacles. Capital goods such as steel, machinery and chemicals became more expensive and difficult to import, and major delays in deliveries were anticipated. Engineers and skilled workers were in short supply. Such issues were aggravated further as many of the existing skilled workers were drafted into the military, and the possibility of recruiting from the Netherlands evaporated after May 1940. The creation of new industries had to be accompanied by the creation of a skilled workforce. ${ }^{25}$

When the Japanese invaded, some of the factories were still under construction, while others were at various preparatory stages. Initially the Japanese did not plan to foster industries in Indonesia. Their plan was to secure the occupied territories in the south as potential markets for the industrial core in the north within their 'co-prosperity

22 Economisch Weekblad (8 Sept. 1941): 2104.

23 De Java-Bode, 17 Oct. and 17 Nov. 1939; 4 and 8 Jan. and 17 Feb. 1940; 28 Oct. 1941.

24 Economisch Weekblad (14 Mar. 1941): 393-6; De Java-Bode, 17 Apr. 1940; 21 July 1941.

25 De Java-Bode, 4 Aug. 1941. 
sphere'. As the war continued and Japan's shipping capacity was crippled, they were compelled to change the plan and foster industries to enable the minimum level of economic self-sufficiency within each of the occupied territories. As a consequence of the more complete economic isolation of Indonesia and the removal of the Dutch engineers, it became harder to obtain capital goods and skilled workers. Apparently for that reason, the Japanese were unable to continue some of the industries that the Dutch had begun. Quinine is one example. Although they did not release the production figures, quinine production apparently dropped during the occupation due to shortages of chemicals necessary for processing cinchona bark. Some people in the quinine distribution system also took advantage of the change in supervision and hoarded much of it. Consequently, the shortage of quinine became acute and innumerable people died from malaria. ${ }^{26}$

In the face of these difficulties, the Japanese built a wide range of makeshift factories. After they surrendered, the Japanese authorities submitted to the Allied Forces various reports, according to which the number of factories and work sites in Java and Madura increased during the occupation in the following way: mines (from 13 to 31), steel (from 0 to 3 ), cables (from 2 to 6), machines (from 23 to 45 ), automobiles (from 31 to 45), bicycles (from 9 to 12), navigation equipment (from 3 to 8 ), batteries (from 2 to 10), timber mills (from 3 to 12), wooden ships (from 1 to 19), rubber (from 9 to 11), printing and ink (from 20 to 22), chemicals (from 5 to 30), fuel (from 1 to 5), alcohol and butanol (from 3 to 7 ), pottery (from 8 to 11 ), cement (from 1 to 21 ), weaving (from 15 to 19), dying (from 4 to 12), kapotex (from 0 to 13), spinning (from 0 to 11), leather (from 7 to 12), livestock (from 6 to12), paper (from 4 to 11), food processing (from 18 to 28), marine products (from 0 to 10 ), tobacco (from 6 to 7 ), medicine (from 5 to 15), hemp bag (from 4 to 12), and others (from 8 to 13). ${ }^{27}$

The document does not specify the criteria used for counting the work sites, and does not provide details of the work carried out, the number of employees or the production capacity of each work site. In 1944, the Japanese Military Administration published a more comprehensive three-volume book of an overview of the industries in Java. The first two volumes survived the war and have been reprinted. ${ }^{28}$ The third volume that was devoted to the manufacturing industries has not been found, which makes it difficult to find out more about the above list. Many were apparently small factories with improvised equipment. Priorities were given to meeting Japanese military needs, but in terms of the amount of items produced and the labour mobilised, civil projects for producing import substitutes were doubtless preponderant.

The lack of import substitutes thwarted many Japanese policies and therefore demanded urgent attention. For instance, they considered education and indoctrination of the local children important, so they tried to double the enrolment in primary schools. School enrolments initially rose, but soon slumped, in part because the clothes children

26 This issue was discussed by the members of the Kyukan Seido Chosa Iinkai [Committee to Investigate Old Customs and Institutions] in its nineteenth, twentieth, and twenty-first sessions held on 15 and 26 July, and 5 August 1943. See 'Panitia adat dan tatanegara dahoeloe, bahagian kesedjahateraan dan kemakmoeran [Committee to investigate old customs and institutions, division on welfare and prosperity]', MINBUZA NEFIS/CMI (collection at the Ministry of Foreign Affairs, The Hague), 3, no. 2241.

27 'List of works, factories and estates with names of Japanese who administered them', MINBUZA NEFIS/CMI, doc. no. 2398.

28 Gunseika Jawa sangyo sokan [An overview of industry in Java under the military administration], vols. I and II (Tokyo: Ryukei Shosha, 1990) (reprinted). 
were wearing were no longer usable. At school there were no writing pads. The Japanese estimated that to provide the schoolchildren in Java with writing pads, no less than 1,000 small factories with 30 workers in each would be necessary. They started making coarse paper using rice straw and other materials, without using caustic soda that had become unavailable. ${ }^{29}$ The above list seems to show that they built only seven such factories. To make up for the deficiency of textiles a type of cloth called kapotex, a mixture of kapok and latex, was produced. Kapotex had originally been developed as a burial cloth, or for making sarongs and other items. Indonesians remember it as a rubber sheet that many of them had to wear.

After the late nineteenth century, the world witnessed phenomenal technological innovations but the fundamental commodities for people were still clothing and food. The total value of imports into Indonesia in 1939 was 472 million guilders, of which clothing materials accounted for 123 million guilders, followed by foodstuffs ( 87 million guilders), machines (61 million guilders), metals (59 million guilders) and chemicals (50 million guilders).$^{30}$ For a good understanding of the socio-economic impact of the European war, textile and food industries can never be overlooked. The next two sections of this article will therefore examine the textile industry in the period from 1939-42, followed by a section on food.

\section{Textiles}

Until the mid-nineteenth century, textile production was an important local industry in Indonesia. From the late nineteenth century, however, the mass-production of textiles in Europe and revolutionary changes in the means of transport enabled large quantities of European-made garments to reach the remotest Indonesian villages at prices lower than those of the local products. This virtually wiped out the local textile industry.

During the First World War, Japan made a powerful thrust into the Indonesian market and, during the worldwide economic depression, almost completely replaced European competitors. Some Dutch officials began to feel that the Indies economy was threatened by the 'inundation' of cheap goods from Japan. As countermeasures, the Dutch authorities switched their economic policies from laissez-faire to more protectionist ones. They imposed restrictions on the importation of Japanese goods, lifted the restriction on importation of power looms from Europe, supplied electricity to designated industrial areas in Java, and enabled the construction of modern weaving-mills there also. In the ten years from 1930, the number of power looms rose from 40 to 6,600, and radically improved handlooms called TIB (named after the Textile Institute Bandung that invented it) increased from 500 to $35,000 .^{31}$

29 See the stenographic record of the nineteenth session of the Committee to Investigate Old Customs and Institutions, held on 15 July 1943.

30 Indisch Verslag 1941, pp. 351-4.

31 About the importation of textiles from the Netherlands and Japan and the development of the industry in Indonesia, see Katoen voor Indië: Sociale ondernemers on het spoor naar vooruitgang 1815-1940 [Cotton for the Indies: Social entrepreneurs on the path to progress 1815-1940], ed. E. J. Fischer (Amsterdam: NEHA, 1994); Sugiyama Shinya, 'The expansion of Japan's cotton textile exports into Southeast Asia', in International commercial rivalry in Southeast Asia in the interwar period, ed. Sugiyama Shinya and Guerrero, pp. 40-73; and Peter Keppy, 'Hidden business: Indigenous and ethnic Chinese entrepreneurs in the Majalaya textile industry, West Java, 1928-1974', Working paper, Vrije Universiteit Amsterdam, 2001. 
Under government protection the Netherlands kept exporting substantial amounts of bleached cotton cloth to the Indies, but this became impossible when the Germans occupied the Netherlands. The Dutch textile industry, unable to obtain cotton and wool, collapsed. The Dutch in Indonesia now started sending clothes to their motherland as well as to the Dutch who had taken refuge in London. ${ }^{32}$ At this juncture the Dutch colonial administration planned to triple the production of textiles in Indonesia in a few years. The outcome surpassed the plan, with production quadrupling in one and a half years. ${ }^{33}$

This dazzling speed of development notwithstanding, Indonesia's weaving capacity at the end of the Dutch era, modern power looms and all kinds of handlooms combined, amounted to no more than one-seventh of local consumption. The industry, moreover, relied heavily on imported yarn, whose price rose by 40 per cent within the first two weeks of September 1939. Meanwhile De Locomotief reported that the developing weaving industry in West Java was experiencing great difficulties in obtaining raw materials, for which no satisfactory solutions had been found. ${ }^{34}$

To produce yarn locally, Dutch colonial authorities ordered spinning machines immediately and began building a spinning-mill. The newspaper reported on 11 November 1939 that 5,000 spindles had arrived. By early 1941, there were two spinning-mills with about 115,000 spindles in total, and construction of a third one was well under way. ${ }^{35}$ However, there was little cotton to spin. Villagers grew some cotton that they partly exported to Japan and partly spun and weaved locally using their manual equipment. Hand-spun yarn was too expensive to be used for mass production. The fibre of the local variety was short and coarse, unsuited for modern power spindles. The Dutch therefore imported cottonseed from the United States and experimented with its cultivation. Dyes used to be imported from Germany, so alternative suppliers had to be located urgently. ${ }^{36}$ In June 1941 a Dutch economist working for the colonial government reported that the shortfall of clothing supplies, coupled with the decrease in the purchasing power of the people, had come to constitute a 'very difficult emergency' ${ }^{37}$

Shortages of clothing, which was already apparent after 1939, became extremely acute during the Japanese occupation. This would not have emerged if Japan, as the largest supplier, had been able to continue exporting cloth. However, Japan too was facing a range of insurmountable problems. Japan's textile industry depended on imported raw materials, mainly cotton and wool. In 1936, importation of these materials constituted 42.4 per cent of Japan's total value of import. Exports of textiles constituted 56.2 per cent of Japan's total export value, making Japan the world's largest exporter of cotton goods. After the outbreak of the second Sino-Japanese War in July 1937, however, Japan's textile industry shrank for two reasons: first, the industrial restructuring in Japan from light industries to war-related heavy industries; and second, the difficulties in obtaining raw materials. The largest suppliers of the main raw material, cotton, were the United States

32 De Java-Bode, 11 July 1940; 20 Feb. 1941.

33 Economisch Weekblad (13 Dec. 1941): 2317; (27 Dec. 1941): 39-45.

34 De Locomotief, 28 and 30 Sept. 1939.

35 Economisch Weekblad (14 Mar. 1941): 396.

36 De Java-Bode, 15 Sept. and 11 Nov. 1939; De Locomotief, 14 Nov. 1939; Economisch Weekblad (14 Mar. 1941): 392-6, and (13 Dec. 1941): 2317.

37 Economisch Weekblad (15 Aug. 1941): 1608. 
and British India. China was the third largest supplier, but the supply from China virtually stopped when Japan commenced its aggression in July 1937. The imposition of the A-B-C-D blockade from July 1941 forced Japan to obtain cotton from areas under its influence. ${ }^{38}$ Although Japan had launched a ten-year project to increase cotton production in Korea, North and Central China, Manchukuo, Taiwan and Kwantung - as selfsufficiency in cotton was an important component of the envisaged 'co-prosperity sphere' - this project was frustrated by the war in China which was not progressing in the direction the Japanese had hoped. ${ }^{39}$

After occupying Southeast Asia, Japan extended cotton production to all of its occupied territories. The target was to start a five-year plan from 1943 and produce about half of the local consumption by 1947 . The consequences were disastrous. It required much labour and land, and ruined food production, but the output of cotton was minimal due to lack of fertilisers, insecticides and know-how. For want of raw materials, the Japanese converted some of Indonesia's weaving machines for the production of storage sacks using sisal (coarse fibre usually used for making ropes and brushes), and shipped some spindles and looms to Malaya. When importation of jute bags from India dropped, the Dutch experimented on producing sisal bags successfully, which the Japanese carried out on a large scale. There was about 2 million tonnes of sugar stored in jute bags. The Japanese shifted half of the sugar into sisal bags and converted emptied jute bags into makeshift clothing. In the final year of the occupation, many people had to wear these makeshift gunnysack clothes. Shortages of cloth became so acute that people were seen walking totally naked both in the countryside and in the cities. ${ }^{40}$

As has been seen, international trading undulated at the beginning, middle and end of the 1930s. Industrialisation in Indonesia, in contrast, showed a linear progression. The Depression and war in Europe did not hinder this trend. They simply worked as sharp spurs on the flank of the colonial administration to accelerate industrialisation. This is reflected in trade statistics that show that overall importation into Indonesia dropped after 1939 but the importation of capital goods and other materials essential for fostering industrialisation showed a marked increase. ${ }^{41}$ The Dutch scheme to create a large industrial complex in Indonesia was, however, a makeshift project conducted hastily without a feasible master plan, as exemplified by the textile industry. It was impossible to transform Indonesia into a fully self-sufficient economic zone in a few years. Nonetheless, the war imposed these impossible tasks upon the administrative authorities.

\section{Food supplies}

The supply of food did not depend on importation as heavily as clothing did, but parallel developments can be observed between the two industries. As the volume of

38 This blockade also meant that the supply of clothing materials from Japan, including yarn that Indonesia's rapidly growing weaving industry so badly needed, stopped months before the Japanese invasion.

39 'Daitoa kokudo keikakuan yoko' [Outline of a proposal for construction of Greater East Asia]', Kishi Shiryo (Kishi Collection held at the Institute of Developing Economies, Chiba) Microfilm 5; Economisch Weekblad (13 Oct. 1939): 1652 and (22 Nov. 1941): 2180-1.

40 For more detail see Shigeru Sato, 'Japanisation in Indonesia re-examined: The problem of selfsufficiency in clothing', in Imperial Japan and national identities in Asia, 1895-1945, ed. Li Narangoa and Robert Cribb (Richmond: Curzon Press, 2003), pp. 350-76.

41 Economisch Weekblad (17 May 1940): 1005-6. 
exports grew after the late nineteenth century, Indonesia came to import increasingly large amounts of food from Mainland Southeast Asia. A turning point in this pattern came during the world Depression when importation of rice for a lowered price destabilised Indonesia's rice economy. The colonial administration intervened, restricted rice imports, and initiated a move towards self-sufficiency in food. The mounting political tension in Europe after 1938 and the outbreak of war in 1939 pushed the Indies administration even further in the direction of self-sufficiency. Instead of Mainland Southeast Asia, it designated Java as the main supplier of rice to deficit areas.

Table 1 shows that importation of foreign rice diminished swiftly but Java was unable to increase its exportation to the Outer Islands as it did not have enough rice for its own population. The overall importation of rice into the Outer Islands thus halved in two years. People's power to purchase food, as has been seen, also decreased in many areas. The colonial authorities were, however, proactive and after 1938 they began systematic preparations for controlling the production and distribution of food. When the war broke out in Europe, they lost no time in drafting the forced cultivation ordinance (teeltdwangordinantie), discussing it at the Volksraad (People's Council, a quasi-parliament without legislative power), and enacting it on 15 September $1939 .{ }^{42}$ The aim was to increase food production in the following areas: East Coast of Sumatra, West Coast of Sumatra, Riau, Jambi, Bangka, Billiton, West Borneo and Manado. Three months later, they added Aceh, Tapanuli, South Borneo and East Borneo to the list.

The government gave local officials stronger powers to intervene in agriculture and to implement the ordinance swiftly and extensively. The weekly organ of the Department of Economic Affairs reported in October 1939 that planting of wet rice in Bangka and Billiton rose by 20 per cent and dry rice by 25 per cent compared with the same season the year before. Seven months later, it reported that the production of both wet rice and dry rice in the same area had increased from the previous year by 48 per cent (land under dry rice by 36 per cent, and productivity per hectare by nine per cent). On 15 December, it reported that wet rice cultivation in Aceh had expanded by 8,000 hectares and that the Agricultural Information Service had provided 40 tonnes of seed. ${ }^{43}$

\section{TABLE 1:}

Importation of rice (January to October, in metric tonnes)

\begin{tabular}{rrrll}
\hline \hline & \multicolumn{1}{c}{ A } & B & C & B + C \\
\hline 1939 & 23,844 & 223,848 & 172,044 & 395,892 \\
1940 & 9,998 & 92,326 & 137,035 & 229,361 \\
1941 & 163 & 44,976 & 150,464 & 195,440 \\
\hline \hline
\end{tabular}

Source: Economisch Weekblad voor Nederlands Indië (20 Dec. 1941): 2342.

A: From foreign countries to Java and Madura; B: From foreign countries to the Outer Islands;

C: From Java to the Outer Islands 
The same organ also reported that in West Borneo, wet rice and other food crop fields had strongly expanded in Pontianak, Sambas and the coastal area of Mempawah. There were similar reports on Sumatra's West Coast, Jambi, Benkulen, South Borneo, Manado and other areas. To enable this, the administration initiated, expanded or accelerated many irrigation projects in the Outer Islands. The budget planned by the colonial administration for irrigation works in 1942 was more than one million guilders higher than that in 1941. This created many employment opportunities for the local people. In eastern Indonesia, where the ordinance was not applied, measures were taken to increase food production by means of growing food crops in people's house gardens. ${ }^{44}$

In rubber growing areas, the rubber boom created manpower shortages. In September 1939 the rubber estates on Sumatra's East Coast recruited 5,000 people from Java. ${ }^{45}$ Many indigenous smallholders throughout Sumatra and elsewhere owned more rubber trees than each household could manage, so they too employed local labour. This prevented the expansion of food cultivation in rubber-growing areas. However, tobacco and other estates were opened to the local people and plantation workers for cultivating food crops. Economisch Weekblad of 1 March 1940 reports that there was a definite expansion of food cultivation by the local people on Sumatra's East Coast by about 10,700 hectares of rice fields, 5,600 hectares of maize fields, 6,400 hectares of cassava fields and 1,500 hectares of other food crops, with an anticipated production increase of 20,000 tonnes of rice and 9,000 tonnes of maize. The large plantation belt in Sumatra's East Coast was used to import substantial amounts of foreign rice but the colonial administration stopped this and designated Aceh in North Sumatra as the supplier of food to this area. Aceh, too, was a rice-deficit region until 1938. To increase rice production in Aceh, the government prepared a special budget for accelerating the existing irrigation expansion projects by shortening them from a few years to a few months, with a view to making 15,000 tonnes of rice available in 1940 for Sumatra's East Coast. By completing the irrigation extension within one season, 10,500 hectares of farmland was to be newly irrigated before the onset of the west monsoon of 1940. The achievement was much higher than the target, and 50,020 tonnes was made available in $1940 .^{46}$

The forced cultivation ordinance was not to be applied to Java, South Celebes, Bali and Lombok, which were designated as the supply bases of rice. That was because land utilisation in these areas was considered to have reached the limit and government intervention into the highly elaborate system of crop rotation was likely to produce undesirable side effects. With or without such an ordinance, however, many export crops lost markets and the land under such crops, owned both by estates and local people, had to be planted with food crops anyway. Java's local administrators too started guiding the people to plant food crops in house gardens and vacant plots of land. Renewed efforts to extend irrigation and drainage channels also began. One example is a ten-year project

44 Economisch Weekblad (1 Mar. 1940): 410; (5 July 1940): 1243 and 1279; (16 Aug. 1940): 1515; (20 June 1941): 1227. See also De Java-Bode (3 Feb. 1940) for irrigation, budget, transmigration and closer relationships between the experimental stations in Java and the Outer Islands.

45 De Java-Bode, 10 and 24 Oct. 1939.

46 De Java-Bode, 29 Sept. and 23 Dec. 1939; 8 Jan. and 3 Feb. 1940; 11 and 13 Oct. 1941; Economisch Weekblad (1 Mar. 1940): 410; (8 Mar. 1940): 384; (3 May 1940): 836; (13 Sept. 1940): 1672; and (1 Jan. 1941): 102-6. 
to transform a vast swampy area in Lakbok, West Java into farmland by constructing drainage channels. ${ }^{47}$

In addition to expanding the land areas under food crops, the colonial authorities also strove to increase food production through improved agricultural methods. For that purpose they strengthened their agricultural research at Bogor, West Java, and spread improved agricultural techniques to the villages in Java as well as other parts of the archipelago. The reforms included the choice of better plant varieties, transplantation of seedlings along straight lines (a method called rijenteelt or rijenbouw in Dutch), more thorough weeding, better manuring, better crop rotations, more intensive land usage and more efficient usage of house gardens, and in the case of agricultural estates, cultivation of food crops for domestic consumption instead of, or in between, export crops. For implementing these reforms, the local bureaucrats also were accorded greater power. ${ }^{48}$

The compulsory cultivation ordinance, although highly successful, provided no more than a partial solution to the problems that were looming large. Before the war, Sumatra's East Coast imported 179,000 tonnes of foreign rice and 8,549 tonnes of Java rice in one year. ${ }^{49}$ The estimated increase in foodstuffs within Sumatra's East Coast and the amount to be shifted from Aceh, although impressive, added up to no more than a small fraction of the rice that used to be imported.

The colonial authorities also altered the system of food distribution. They were able to respond to the European war swiftly because they had learned hard lessons from the First World War, which caused havoc to the rice market in Indonesia although the Netherlands remained neutral. A blockade of sea transport, the influenza pandemic and harvest failures combined to more than triple the price of rice in Indonesia in the wake of the previous war..$^{50}$ One year before the outbreak of the European war, in September 1938, they anticipated the coming conflict and started preparations for creating a system to impose government control over food distribution. On 25 April 1939 they set up the Voedingsmiddelenfonds (Foodstuffs Funds) to finance government controls over the purchase, storage and transportation of foodstuffs. In 1940 they established the Rijst Verkoop Centrale (Rice Sales Centre), and obliged rice mills in each residency to sell the milled rice exclusively to it. The purchased rice was partly marketed locally, and partly stockpiled near the major harbours along the North Coast of Java and in the Outer Islands. ${ }^{51}$

Economic speculators also learned lessons from the First World War. No sooner did the news of the outbreak of the war in Europe reach the Indies than they began hoarding rice. The government had been, however, well prepared for countering such activities. The Voedingsmiddelenfonds began to buy rice directly from markets and was able to provide fresh supplies to deficit areas. The price rises and market confusions were therefore

47 De Java-Bode, 30 Sept. and 5 Oct. 1939

48 Economisch Weekblad (5 Jan. 1940): 1507-8; De Java-Bode, 21 Sept. 1939; 3 Feb. 1940.

49 Economisch Weekblad (22 Sept. 1939): 1566.

50 Changing economy in Indonesia: A selection of statistical sources material from the early $19^{\text {th }}$ century up to 1940, vol. 4, Rice prices, ed. P. Creutzberg (The Hague: Martinus Nijhoff, 1976), p. 86, Diagram E.

51 For an overview of the Dutch colonial government's food policy in this period, see 'Voedselproblemen en overheidspolitiek op Java en Madoera [Food problems and the government policies in Java and Madura]', Koloniaal Tijdschrift, (Dec. 1940): 643-715. 
only temporary and the prices soon sank lower than the pre-war level. The Indies administration was thus able to keep the negative impact of the war to a minimum, according to a government publication..$^{52}$

The government's attempt to monopolise the distribution of machine-milled rice was, however, not free from problems. One negative side effect was the compartmentalisation of rice distribution along administrative divisions, which hindered a free flow of food from surplus areas to deficit areas, contrary to intention. This was observed within Java as well as between Java and the Outer Islands. Although the forced cultivation of food crops and the new distribution system were in place, per capita consumption of rice in certain parts of the Outer Islands noticeably dropped..$^{53}$

The changes in food distribution were accompanied by changes in social relations. Until the onset of the world Depression, people in the cities and areas with strong export industries consumed much imported rice, while people in rice-growing villages consumed locally produced rice. When the government restricted importation of foreign rice, Indonesia's rice started to flow from the countryside to the cities and plantation areas. This enhanced the commoditisation of local rice, and stimulated proliferation of rice-mills that had been relatively few until then. Ethnic Chinese, who had been dominant in the rice-importing business, now moved into the rice-milling industry and quickly established a virtual monopoly. Within a decade Java's milling capacity tripled, and came to process over 20 per cent of rice produced in Java. ${ }^{54}$

This had a negative effect on Java's peasantry. Harvesting and pounding of rice were important sources of income, particularly for women of landless households. When ricemills cropped up, rice brokers appeared in the villages and bought crops from large farmers when rice was still standing in the fields. They brought in gangs of harvesters from outside, and deprived many local women of their sources of income. ${ }^{55}$ The purchase of rice by outsiders also caused a price rise. Large farmers profited from it but small rural consumers, including landless peasants who constituted the majority of the rural population, suffered from the combined effect of decreased incomes, decreased availability of food, and the increased price of food. Their mounting frustration and anger were ready to explode, and when the Japanese Army invaded, Indonesians in many places assaulted and destroyed rice-mills and looted Chinese shops. Behind this was the government-led reform, which exacerbated the long-standing ethnic conflicts in Indonesia.

Rice-mills were nonetheless indispensable tools for the government control of rice distribution, so the Netherlands Indies government planned to finance construction of more rice-mills in Aceh and Sumatra's East Coast as well. Ethnic Chinese immediately showed interest in it. The government passed an enterprise regulation ordinance on rice-mills and created millers' associations as they had in Java. All of the rice that was machine-milled in Aceh, except that in Alaslanden, was to be shipped exclusively

52 Economisch Weekblad (8 Sept. 1939): 1479; (24 Nov. 1939): 2012.

53 De Java-Bode, 30 Oct. 1940.

54 Economisch Weekblad (8 Nov. 1940): 2065-7. Rice-milling became Indonesia's fourth largest industry in terms of the total wages paid to the workers.

55 This issue was discussed repeatedly at the Volksraad particularly by its member Prawoto Semodilogo. See the Handelingen van den Volksraad [Procedings of the People's Council] 1939, Ond. 1. - Alg.Ged. Stuk 3, p. 36 and Stuk 4, p. 26; 1941, Ond. 1. -Alg.Ged., pp. 216-17. 
to Sumatra's East Coast. ${ }^{56}$ In 1939 Aceh had 18 mills that in total produced 9,019 tonnes of cleaned rice. A Japanese administrator inspected the region in early September 1942 and reported that there were about 40 mills in Aceh, half owned by Chinese and half by Acehnese; about 40,000 tonnes of milled rice was exported from Aceh to Sumatra's East Coast, and this exportation was still being handled by the Dutch. ${ }^{57}$

The Japanese Military Administration inherited the reforms that the Dutch had started with regards to the production and distribution of food. The Japanese conducted intensive campaigns to increase food production from late 1943, and carried out irrigation extension projects at 62 locations in Java and several places in the Outer Islands. The irrigation projects in Java were apparently based on information that Sukarjo Wiryopranoto and other Indonesian officials submitted to the occupation government. ${ }^{58}$ The Japanese extended or modified the pre-existing projects. As has been seen, the Dutch shortened the existing irrigation projects in Aceh from a few years to a few months, and started a ten-year project to construct drainage channels in Lakbok. The Japanese shortened the project in Lakbok from ten years to two years, to convert a swamp of 5,000 hectares into farmland with a budget of 770,000 guilders. ${ }^{59}$

To increase the productivity per area, the Dutch initiated a reform in the method of rice cultivation. The reform in rice farming is widely perceived to have been introduced by the Japanese. The reason is that the Dutch implemented it in the Outer Islands, whereas the Japanese did so in Java and propagandised it as their own. The Netherlands Forces Intelligence Service (NEFIS) stationed in Australia analysed Japanese radio propaganda and sought the opinion of a Dutch agriculture specialist, who commented that most of the Japanese 'innovations' were 'mere continuation $[s]$ of the methods practiced under the Dutch' ${ }^{60}$ The essence of the reform was a move towards the more labourintensive method of rice cultivation that was practised in Japan at that time. We can argue therefore that it was the Dutch who started the 'Japanisation' of rice farming in Indonesia.

The Japanese endeavoured to increase rice production in Java not so much because they needed food for their own consumption but rather because their large-scale project to grow cotton and some other non-edible crops (such as jute, ramie, roselle and castor plant) undermined food cultivation in Java. The campaign was a desperate attempt to mitigate the disastrous effects of their occupation on the local economy. ${ }^{61}$ To propagate the 'new' methods, the Japanese agricultural instructors waded into paddies to show object lessons, and requested upper-level Indonesian government officials to do the

56 The number of fully operative rice-mills in the Outer Islands increased from 228 in 1935, to 361 in 1938, and to 510 in 1940. Economisch Weekblad (15 Nov. 1941): 2160.

57 Sakakibara, Masaharu, Ichi chui no tonan ajia gunsei nikki [A first lieutenant's diary on the military administration in Southeast Asia], Tokyo: Shisosha, 1998, pp. 268-9; Economisch Weekblad (8 Nov. 1940): 2068.

58 See Sukarjo's speech at the fifteenth session of the Kyukan seido chosa iinkai held on 5 June 1943.

59 'Study of irrigation in Java/Madura', MINBUZA NEFIS/CMI, bijlage 3, 1776.

60 'Rice position in Java', MINBUZA NEFIS/CMI, deel 1, 1775.

61 This issue was discussed in the Kyukan seido chosa iinkai, at the twenty-second, twenty-third and twenty-fourth sessions held respectively on 15 and 25 Aug. and 25 Sept. 1943. For a more detailed study see Shigeru Sato, 'The "economic soldiers" in Java: Indonesian laborers drafted for agricultural projects', in Asian labor in the wartime Japanese empire: Unknown histories, ed. Paul Kratoska (New York: M.E. Sharpe, 2005), pp. 129-51. 
same, disregarding local cultural sensitivities. They also instructed Indonesians to use animal and human waste as fertilisers, which local people usually threw away. In certain areas where the reforms were thoroughly implemented, rice production seems to have increased substantially. For instance, the agricultural committee of the regency of Sidoarjo reported in October 1946 that the average annual production of rice in the regency $-453,766$ tons in the five years before the occupation - had increased to 634,794 tons during the occupation. The report explained that unlike the Dutch, the Japanese paid greater attention to rice production. However, in 1946 Sidoarjo became a battlefield, with many villagers joining the revolution. The workforce that remained in the villages was insufficient to carry out food cultivation, and irrigation water was not regulated properly. As a result, rice production fell to 360,958 tons in $1946 .{ }^{62}$ This kind of success under Japanese rule was, however, limited to certain regions, and overall food production in Java dropped, as we shall see in the following section.

With regards to rice distribution, Dutch policy was also a prelude to Japanese policy. Both the Dutch and Japanese made use of Chinese rice-millers to control food distribution, to the detriment of small peasants. The situation worsened under the Japanese partly because they made two major mistakes in implementing the system. One was the allocation of quotas to the residencies and principalities. The distribution of rice-mills was not proportional to the amount of rice produced in each residency. In January 1940, Bogor had 93 mills, Jakarta had 91, Besuki had 56, whereas Madura had none, Madiun and Bojonegoro had six each, and Yogyakarta had nine. The mills in the concentrated areas used to buy large quantities of paddy from nearby regions including other residencies using the railway system and trucks. The Japanese based the quota allocation on the record from the Dutch period. This made the delivery quotas for the highly mechanised residencies too high for the local farmers to meet. To rectify this situation, the Japanese shifted 40 mills in Bogor to other residencies in Central and East Java where there were fewer mills. ${ }^{63}$ They also converted some sugar factories into rice-mills and adjusted the delivery quotas to some extent but these measures were insufficient to solve the problem.

The other problem was the involvement of local administrators in this system. To maximise the delivery of rice to the local government, many local administrators banned exportation of rice from their administrative divisions such as residency, regency and district. At the village level, village heads were responsible for allocating quotas to villagers, and these officials were usually the largest landowners. Many of these officials used to sell their crops to the mills. During the occupation, they avoided selling their crops to the mills because the price of rice had recovered by 1943 from the initial fall, and the black market price of rice became higher than the official one. When village officials avoided delivery, the quotas had to be allocated to small farmers in the village. Thus small farmers were obliged to deliver their crop to the mills. This was the beginning of the notorious

62 Party Politik Islam 'Masjoemi', Tjabang Sidoardjo, 'Pedoman tentang daja oepaja oentoek menambah hatsil pertanian dalam daerah kaboepaten Sidoardjo' [Political Party, Masyumi, Sidoarjo Branch, 'Guidelines for all efforts for increasing agricultural production in the regency of Sidoarjo'], 22 Oct. 1946, MINBUZA NEFIS/CMI, bijlage 3, 3145.

63 Iwatake Teruhiko, Nanpo gunseika no keizai shisaku: Marai, Sumatora, Jawa no kiroku [Economic policies in the southern regions: A record of Malaya, Sumatra, and Java] (Tokyo: Kunko Shoin, 1981), vol. I, p. 200. 
'forced delivery of rice'. The total amount delivered, however, dropped constantly. The occupation administration put great pressure on the farmers but they were never able to buy the amount that had been bought by the Rijst Verkoop Centrale in the Dutch period. Small farmers, however, suffered much more bitterly than before the Japanese invasion. Consequently, assaults on Chinese people and their properties by Indonesians became much worse and more widespread after the Japanese surrender than during their invasion. Village officials and other local officials were also targeted. ${ }^{64}$

\section{Employment}

There is relatively little information on employment in published materials. The available statistics show that unemployment decreased from 19,233 persons in 1939 to 15,765 persons in $1940 .{ }^{65}$ Those statistics are, however, extremely partial, only showing the numbers of registered jobseekers. These people consisted of Europeans, a handful of privileged indigenous people and so-called foreign Orientals, a minute fraction of the total working population. Statistics on unemployment benefits are also available, but 90 per cent of the recipients were Europeans. Those who were most vulnerable to economic fluctuations, such as plantation coolies and seasonal employees, and other workers in miscellaneous fields such as transportation, cottage industries and retail businesses, were not included. No attempt was made to produce statistics, or estimates, of how those people were affected by the European war.

The war's impact on employment was evidently uneven as has been exemplified by the cases of rubber and copra. Within Java, a regional difference was observed between the western half and eastern half of the island. Export crops such as sugar, coffee and tobacco were grown mostly in the eastern half, while tea, rubber and cinchona plantations were found primarily in the western half. When the war spread in Europe, the plantation crops in the western half were able to find alternative markets to varying degrees whereas those in the eastern half failed to do so. The sugar plantations alone employed 55 per cent of full-time plantation workers in Java when the census was taken in 1930 . Consequently, unemployment and destitution became markedly more serious in the eastern half. ${ }^{66}$

There are contemporary observations that some of those who had lost employment in the cities and plantations returned to their villages, while those who had lost their livelihood in the countryside migrated to the cities and resorted to, among other things, begging and prostitution. In eastern Java prostitution became extremely prevalent. Cases of venereal diseases, which were already widespread before the war, consequently increased. The cost of living also rose gradually. In Jakarta, the cost of living for the households in Group One (the group with the lowest monthly household income of 30 guilders on average) increased 19 per cent between July 1939 and September 1941, due

64 For more detail see Shigeru Sato, War, nationalism and peasants: Java under the Japanese occupation 1942-1945 (St Leonards: Allen and Unwin; New York and London: M.A. Sharpe, 1994), pp. 115-53.

65 Indisch Verslag 1941, p. 257. Economisch Weekblad and some newspapers also reported monthly on unemployment figures in the same manner, based on the data released from the Central Bureau of Statistics.

66 Voedselproblemen en overheidspolitiek op Java en Madoera, pp. 643-55. See also the articles on export industries in De Java-Bode (20 Sept. 1940; 17 Jan. 1941). 
primarily to price rises in food and clothing. The highest income earning group's cost of living also rose but it was because their expenditures on properties rose. High-income earners' salaries were raised in response to inflation. A need to raise unskilled workers' wages was also recognised but they remained static until the end of the Dutch era. ${ }^{67}$ The colonial government had to prepare special budgets for their industrialisation effort, irrigation extension and forced cultivation, and defence preparations and subsidies for the export industries that had lost markets. The total amount of money in circulation steadily increased but availability of consumer goods diminished. An inflationary trend, although reportedly the lowest in the world at that time, became apparent, and this threatened the survival of the poorest of the society. Health problems due to malnutrition increased and spectres of hunger oedema began to appear. Death rates rose in certain regencies and surpassed birth rates, which declined. There was a visible deterioration in socio-economic conditions in the Netherlands Indies after 1939. ${ }^{68}$

Dutch publications, and the members of the Volksraad, often used expressions like 'in this difficult time', which reflect the lowering general standard of living among the masses of people. The symptoms of economic woes were, however, undoubtedly much milder than in the Japanese era. One reason was that loss of jobs and creation of jobs occurred simultaneously, particularly in the Outer Islands. The decrease in overall volume of international trade doubtlessly created a substantial amount of unemployment, but it was accompanied by a boom in certain sectors such as the government-led industrialisation including the rapid increase in weaving-mills and rice-mills, and irrigation extensions and other works in relation to the compulsory cultivation ordinance. In Java and Madura, thanks in part to favourable weather, the rice harvest was also a record high in 1941, ten per cent more than the ten-year average from 1931 to $1940 .{ }^{69}$

Aceh provides a typical example of losses and gains of employment occurring simultaneously. From 1938 to 1940, exportation of copra from Aceh dropped from 678,000 to 135,000 guilders, pepper from 208,000 to 12,000 guilders, and areca from 2,205,000 to 451,000 guilders, whereas native rubber increased from 543,000 to 3,000,000 guilders. The overall drop in value was relatively small, from 3,634,000 to $3,598,000$ guilders. Moreover, rice cultivation and milling were, as has been seen, substantially expanded and 50,020 tonnes of rice were made available in 1940 for exportation to Sumatra's East Coast. ${ }^{70}$

During the Japanese occupation, loss and creation of employment occurred separately, the one followed by the other. When the Japanese invaded in early 1942, many workers in export-import industries lost their jobs. It was not until late 1943 that the

67 De Java-Bode, 25 Nov. 1940; 29 Mar. and 4 Aug. 1941; Economisch Weekblad (27 Sept. 1941): 1865.

68 Indisch Verslag 1941, pp. 248 and 262; the article 'Hongeroedeem [hunger oedema]' in De Java-Bode, 29 Apr. 1940. See also the speeches by Sutarjo and Mak Mansur at the second session of the Kyukan seido chosa iinkai, held on 26 Dec. 1942. Doctor Buntaran Martoatmojo conducted research at Semarang Central Hospital, and his findings were published in journals. See, for example, his article 'Pemandangan singkat perihal kesehatan dan makanan rakjat dll [Brief overview of the people's health and food etc.]' in Berita Ketabitan [Medical News], nos. 4, 5, 6, MINBUZA NEFIS/CMI, bijlage 3, 2475. See the stenographic record of the nineteenth, twentieth, and twenty-first sessions of the Kyukan seido chosa iinkai held respectively on 15, 26 July and 5 Aug. 1943.

69 De Java-Bode, 5 Sept. and 1 Oct. 1941.

70 De Java-Bode, 13 Oct. 1941. 
Japanese commenced a systematic mobilisation of labour. As a result, Indonesia witnessed an extreme fluctuation from large surpluses to acute shortages of manpower. At the beginning, all plantations had to retrench most of their employees, retaining only the minimum number of maintenance workers. No reliable overall statistics are available but the cessation of tea production in Java alone was estimated to have contributed 200,000 people to the pool of unemployed. In Pekalongan, Central Java, no less than 20,000 workers in batik and weaving industries became unemployed. ${ }^{71}$ In 1940 registered jobseekers were 15,765 persons in the whole of Indonesia. At the second session of the Kyukan Seido Chosa Iinkai (Committee for Investigating Old Customs and Institutions), Mohammad Hatta reported that Jakarta alone had some 30,000 registered jobseekers. Wondoamiseno added that in the city of Bandung the registered jobseekers were 33,361 persons, of whom no more than 2,296 persons were subsequently able to find a job. Many of the unemployed were former personnel of the Royal Netherlands Indies Military (KNIL). The Indonesian intellectuals in the Kyukan Seido Chosa Iinkai discussed social and economic issues including the period after 1939. Among the Indonesian members of the Committee there was initially a general consensus that unemployment was by far the most serious social issue that the Japanese Military Administration faced in Java. Some Indonesian members proposed to investigate the situation but the Japanese disallowed the proposal.

From late 1943, however, the Japanese conducted a campaign for 'total mobilisation' and created labour shortages in the notoriously 'overpopulated' island of Java. They even mobilised the homeless in the cities and the maintenance staff in plantations. The Japanese launched the mobilisation campaign under the banner of 'defence and production increase'. The forced mobilisation of labour is usually attributed to the Japanese 'defence' effort. In eastern Indonesia the labour mobilisation for defence purposes indeed created manpower shortages. ${ }^{72}$ In Java where the mobilisation campaign was most intensive, it was 'production increase' that took the preponderant part of the mobilised labour. That was because economic self-sufficiency was more difficult to achieve in this 'overpopulated' island than elsewhere. The most important target items for 'production increase' were food and clothing for the 50 million people, followed by coal to fire the steam locomotives, wooden ships for inter-island transportation and numerous other miscellaneous items.

The effect of economic isolation on employment can be illustrated with a case of coal mining in Java. Before the Japanese invasion, Sumatra and Borneo were the main producers of coal within Indonesia, and Java was the main consumer. There were no coal mining operations in Java. As soon as the Japanese occupied Java, they discovered that coal was in short supply and they did not have a sufficient shipping space for shifting coal from the adjacent islands. Before the Japanese invasion, about 70 per cent of all the ships that operated between Indonesia's ports and foreign ports belonged to Great Britain and the Netherlands; Japan's share was no more than eight per cent in tonnage. ${ }^{73}$

71 See the speeches by the chairperson, Mohammad Hatta, and Wondoamiseno at the second session of the Kyukan seido chosa iinkai held on 26 Dec. 1942.

72 Remco Raben, 'Indonesian romusha and coolies under naval administration: The eastern archipelago, 1942-1945', in Asian labor in the wartime Japanese empire: Unknown histories, ed. Paul Kratoska (New York: M.E. Sharpe, 2005), pp. 197-212.

73 Indisch Verslag 1941, p. 395. 
Most of the ships that belonged to the Allied countries had left the area prior to the Japanese attack. Japan lacked the shipping capacity to maintain the economy within its 'co-prosperity sphere' even if there had been no destruction of ships. After the invasion, the Japanese used about 40 per cent of the inter-island shipping space for shifting coal but the amount Java was able to receive was no more than a small fraction of the prewar imports. Java's railway system, thermal power stations and various factories could not operate without coal. This would paralyse Java's economy. The Japanese therefore decided to start coal mining at six places within Java.

The largest coal exploitation was conducted in Bayah, West Java. One of the smaller ones was in the district of Tegalombo, Madiun, East Java, which a Japanese company, Ishihara Sangyo, began mining from April 1944. ${ }^{74}$ They started open-cut mines in the middle of the jungle, and the distance from the mines to the nearest road on which carts could operate was 40 kilometres. Instead of building a road or a railway, the company mobilised hundreds of local people to carry dugout coal on their backs. A return trip along a narrow mountain pass, badly needing repairs, took a few days. Wages were 22 cents per day for a male, and from 10-15 cents for a female, which were paid monthly. The amounts of coal obtained in this way, and from other sites in Java, were so small as to be negligible. The shortage of coal became more and more acute although there was a glut in the adjacent islands. Consequently, the railway's transportation capacity dropped. In early 1945, however, the Japanese decided to discontinue the operations in Tegalombo because labour production efficiency was obviously too low even in this emergency situation. ${ }^{75}$

Although the gravity and severity of the impact of the Dutch and the Japanese administration is incomparable, there were some common matters, such as the isolation of Indonesia from the rest of the world, requiring economic re-organisation. It created unemployment on the one hand, and demands for labour for producing import substitutes on the other. This necessitated a relocation of labour. As isolation progressed, people were compelled to work harder to obtain fewer resources. That was because the production efficiency of labour dropped when the economy became isolated. In other words, the economic value of labour depreciated due to the comparative disadvantage of a closed economy. That was the fundamental reason behind the extensive mobilisation of labourers euphonically called 'economic-soldiers'. As the isolation process progressed from 1939 onwards, some early symptoms of the economic and social woes emerged even before the Japanese troops invaded Indonesia.

To justify the mass labour mobilisation, the Japanese propagandised that becoming romusha (drafted labourers) was as noble and useful an act as becoming a soldier who defends his Fatherland. In reality, many of the projects for which the Japanese mobilised labour, such as coal mining, extension of irrigation works, cultivation of cotton and producing writing pads for children, had little to do with supporting their military operations. The mobilisation was a struggle to mitigate the negative economic side-effects

74 For the mines in Bayah see Sato, War, nationalism and peasants, pp. 179-86. The most comprehensive extant document about all the mines in Java is 'Tonai kaku kozan gaikyo [Overview of the Mines in Java]' (BUZA NEFIS/CMI, bijlage 3, 2043), which was produced for internal use by the Mining Section within the Department of Industry of the Military Administration in Java. It is, however, the conditions at an early stage, as of Apr. 1944.

75 Jawashinbun [Java Daily], 30 Nov. 1944. 
their military occupation made on the occupied land. The Japanese overworked mobilised workers but the availability of essential commodities that they tried to produce locally diminished swiftly. Towards the end of the occupation, Indonesia was on the verge of an economic catastrophe.

The 'total mobilisation' campaign removed so much labour from farming villages that it caused a sharp drop in food production. A compilation of reports on production and delivery of food crops from each residency and principality as of 4 August 1945 reveals this. ${ }^{76}$ Early August was the time when the main harvest season was already over and two-thirds of the annual delivery quotas ought to have been fulfilled. Banyumas residency reports that 'the area under cultivation decreased due to a manpower shortage caused by rising death rates.... Shortage of seed rice is 600 tonnes. Delivery as of 4 August is 28.7 per cent [of the quota for the year].' The resident of Kedu states, 'the stock of foodstuffs [will last] up to 15 October. Since the outbreak of war, agricultural production constantly declined. . . Farmland left uncultivated is 16,000 hectares. . . Manpower shortage is 100,000 persons. Deaths from January 1944 to March 1945 are 60,000. Malaria patients are 300,000. Achieving the delivery quota is extremely difficult. As of 4 August, 29 per cent has been achieved.' The report from Pati residency is even more extreme; 'Rice production in Pati is five to six quintals per hectare due to manpower shortage. ... About 125,000 farmers had been mobilised as coolies. The delivery quota for this year is 60,000 tonnes whereas the estimated production is 54,000 tonnes.'

The reliability of the above reports written by Indonesian administrators at the residency level and submitted to Jakarta around the time of the Japanese surrender, must be said to be open to doubt. Java's average production of rice per hectare was 21.5 quintals before the war. The total production in Pati in 1940 was 360,600 tonnes, and the delivery quota for 1945 was 45,000 tonnes according to other official sources. The above report from Pati means that the rice production in that residency dropped to a mere 15 per cent of the pre-war level. Such a sharp drop would have caused a great famine but there is no report of a famine of such magnitude. There is, however, much evidence and reports, both from Indonesians and Japanese, that so much labour was drafted from agrarian communities that food production in Java dropped substantially, if not as catastrophically as the above reports state, and shortages of food and increase in illnesses and deaths due to malnourishment were observed throughout the island.

The Japanese administrators and their Indonesian agents targeted in principle the 'non-essential work force', such as landless peasants, for labour mobilisation. This seemingly redundant work force, in reality, carried out much agricultural work during the busy seasons. Systematic relocation of the village poor deprived many villages of the essential labour for farming.

\section{Causality, change, continuity and legacy}

The sharp drop in the general standard of living in Indonesia during the occupation is usually attributed to ruthless exploitation by the Japanese. Exploitation as an analytical concept, however, needs to be applied with care. The motivation behind the Japanese invasion was indeed resource exploitation. The resources that they aimed to exploit were,

76 'Keadaan tanaman di Djawa pada tahoen 1945 [Conditions of crops in Java in 1945]', Algemene Secretarie te Batavia 5656, The National Archive, The Hague. 
first and foremost, strategically important items such as oil, rubber and tin. The amount of these resources obtained was a small fraction of what Indonesia used to export. From people with few resources, the Japanese exploited labour and rice. The existing literature does not question the reasons the Japanese exploited so much labour and rice, assuming that they had unlimited needs and the capacity to exploit them. The occupation created a large number of unemployed, and the Japanese needed labour for their military projects. This newly created unemployed workforce should have been sufficient to meet needs, and Indonesia should not have suffered from chronic unemployment throughout the occupation. If the Japanese needed rice for their own consumption, a campaign of forced rice delivery was not necessary. The Japanese population in Java fluctuated, but was about 50,000 people. If each of them consumed 600 grams of rice per day, they would have needed about a 10,000 tonnes of rice per year. There were in Java about 500 mills. Several large mills had a milling capacity over 10,000 tonnes per annum. Therefore one large mill could have supplied the entire Japanese population in Java with sufficient rice.

This interpretative conundrum can be broken to an extent if we differentiate exploitation from exploitative intention. The latter was much more harmful than the former. Japan entered the war with an intention to exploit resources. They failed to accomplish this but their actions altered the overall regional and global economic structures. This structural change affected all aspects of economic life in Indonesian in a complex way.

In the conventional historiography of Indonesia, the Second World War is equated with the Japanese occupation, and 1942 is a year of sudden change. This article has demonstrated that there was in fact a prelude to these changes, many of which were related to transformations in the global economic structure due to the Second World War, and countermeasures by the state authorities, all of which began well before the Japanese invasion. The fundamental problem for Indonesia was the gradually deepening economic isolation that necessitated state intervention.

In a recent study of the world depression in Southeast Asia, it is argued that:

the most substantial long-term impact of the depression ... was ... to advance greatly the role of the state in the economy, in the direction of protection and self-sufficiency ... And in the Netherlands East Indies, towards the close of the 1930s the administration took on the enormous task of regulating virtually all aspects of local industrial production - setting prices and output even at plant level. ${ }^{77}$

As usual, these scholars stopped their investigation around 1939. If we extend our scope a little further, it becomes obvious that state intervention intensified in late 1939, again in early 1942, and yet again in late 1943.

State intervention and economic re-organisation started during the world depression, and gradually intensified across the regime change. The steady decline of international trade before the Japanese invasion disrupted Indonesia's economy to such an extent that setting up the 'Committee for Economic Re-Organisation' became a focal point of intensive discussion in the Volksraad in $1941 .^{78}$ The Japanese who invaded

77 Weathering the storm: The economies of Southeast Asia in the 1930s depression, ed. Peter Boomgaard and Ian Brown (Singapore: Institute of Southeast Asian Studies; Leiden: KITLV, 2001), pp. 11-12.

78 See Handelingen van den Volksraad, 37 $7^{\text {ste }}$ Vergadering - Maandag 18 Augustus 1941, pp. 943-86. 
several months later deliberately copied the Dutch policies in many instances partly because the similar situations required similar policies.

Locating the roots of this problem in the Dutch period is not the same as shifting the responsibility from the Japanese onto the Dutch. The gradual economic isolation will only explain the reason for state intervention but not its manner. One reason why the symptoms of the negative impact of the war were much milder during the Dutch period than in the Japanese period was that the Dutch administrators were much more experienced and prudent than the Japanese, and skilfully minimised the negative impact of the war. The Japanese inherited Dutch policies in broad outlines but the manner in which they enforced the policies, such as the forced delivery of rice and forced mobilisation of labour, were obviously inappropriate and worsened the economic conditions. Also, the responsibility for starting the reckless war under the groundless slogan of 'co-prosperity', and forcibly implementing badly formulated policies in the newly occupied economically isolated territories, remains with the Japanese.

Although Dutch administrators were more proactive, prudent and skilful than Japanese administrators, it became obvious during the Dutch era that the forced economic isolation had created insoluble problems. Dutch rule, however, came to an end before these problems started truly affecting the daily lives of the people. It was the Japanese who faced the problems and aggravated the situation by grappling with these problems in their notoriously inappropriate manner.

The Japanese occupation influenced Indonesia, both negatively and positively. In the 1950s, conflicts emerged between the Dutch who came back to reclaim their rights over the former agricultural estates and the farmers who had been cultivating the land after the Dutch were put in Japanese concentration camps. This is often considered to be one negative legacy from the occupation era. We have seen, however, that the Dutch colonial administration started opening up the tobacco and other estates in the East Coast of Sumatra for the local farmers to grow food crops. As a positive legacy, some see a link between the agricultural reforms during the occupation and the Green Revolution in Indonesia in the 1980s. Cotton cultivation, textile industry, shipbuilding and various other industries are also thought to have started during the occupation and developed after the independence. ${ }^{79}$ Many Japanese who were involved in the agricultural reform or the 'industrialisation' effort seem to believe that they laid the foundation for the post-war economic developments in Indonesia, and therefore their endeavour was not in vain. We have seen, however, that it was the Dutch who started to move into this direction. Contextualisation of the impact of the war leads us to a thorough re-examination of the questions of causality, change, continuity and legacy.

79 For a recent discussion of this issue by an Indonesian historian see Nawiyanto, The Rising Sun in a Javanese rice granary: Change and the impact of Japanese occupation on agricultural economy of Besuki, 1942-1945 (Yogyakarta: Galang Press, forthcoming). 